\title{
Age-Related Changes in the Expression of ICAM-1 in the Aorta of Wistar Albino Rats
}

\author{
Cambios relacionados con la Edad en la Expresión de ICAM-1 \\ en la Aorta de Ratas Wistar Albinas
}

\author{
Sennur Ketani*; Zelal Karakoç ${ }^{* *}$; M. Aydın Ketani**** \& Mehmet Kilinç*****
}

KETANI, S.; KARAKOÇ, Z.; KETANI, M. A. \& KILINÇ, M. Age-related changes in the expression of ICAM-1 in the aorta of Wistar albino rats. Int. J. Morphol., 34(4):1482-1486, 2016.

SUMMARY: ICAM-1 which is expressed by endothelial cells and leukocytes are observed as first markers in diseases such as transplant rejection, diabetes and atherosclerosis and in infections caused by various pathogens. In the present study, it is aimed to reveal the age-related changes in the expression of ICAM-1 on rats. Therefore, a total of 30 albino rats were taken at the age of 6,18 and 24 months without gender discrimination. Rats were fed with standard pellet feed during the study. Afterwards, rats were sacrificed and tissue samples were collected from their rats, and the samples were evaluated under the light microscope by staining with immnunohistochemical method. It was determined that the expression of both aortic endothelial cells and endothelial cells in the media layer had been significantly increased based on the age.

KEY WORDS: ICAM-1; Rat; Aortic endothelium; Age.

\section{INTRODUCTION}

Adhesion molecules have a role in the regulation of conditions including cell recognition, specific cell migration, embryogenesis, cell growth, cell differentiation, cell-cell and cell-matrix interactions and inflammation. They are subdivided into four groups; integrins, selectins, cadherins and members of the immunoglobin superfamily (Holtfreter, 1948; Frenette \& Wagner, 1996).

The members of immunoglobin superfamily have possibly originated from a common precursor gene as a result of various evolutions. These molecules can either form homophilic or heterophilic interactions. There are five types of ICAM in immunoglobin superfamily (Funatsu et al., 2001). Intercellular adhesion molecules-1 (ICAM-1) and ICAM-2 are counter-receptors for the CD11/18 integrins. ICAM-1 and ICAM-2 are mostly synthesized by vascular endothelial cells; however, ICAM-3 is synthesized by resting lymphocytes (Hernandez-Caselles et al., 1993).

Among the well-known and important adhesion molecules, ICAM-1 was first shown by immunoblotting method in serum in 1991. It has both N-terminal and C- terminal ends (Springer, 1990). It is expressed by vessel endothelial cells and leukocytes (Springer).

ICAM-1 is expressed in low amounts in various cells such as endothelial cells, lymphocytes and monocytes under normal conditions; whereas, its expression is enhanced by the effects of cytokines such as IL-1, TNF-alpha and IFN-gamma. This enhancement is shaped in the areas of acute and chronic inflammation. ICAM-1 is combined with LFA-1 which is found in all leukocytes of integrin family and mainly with macrophage antigen-1 (Mac-1) which is present in neutrophils, monocytes and eosinophils. The proteolytic dissociation of extracellular part of ICAM-1 forms soluble ICAM-1 (sICAM1) (van de Stolpe \& van der Saag, 1996).

ICAM-1 is shown as a first marker in inflammatory infections caused by various pathogens such as HIV-1 and allergic rhinitis, and in diseases including transplant rejection, diabetes and atherosclerosis. ICAM-1 acts as a receptor of Plasmodium falciparum (malaria factor) and rhinoviruses (important reason of common cold) (Hernandez-Caselles et al.). Plasma levels of ICAM-1 shows parallelism with the

\footnotetext{
* Department of Biology Education, Ziya Gökalp Education Faculty, University of Dicle, Diyarbakır - Turkey.

** Department of Histology and Embryology, Veterinary Medicine Faculty, University of Siirt, Siirt - Turkey.

*** Department of Histology and Embryology, Veterinary Medicine Faculty, University of Dicle, Diyarbakır - Turkey.

***** Department of Anatomy, Veterinary Medicine Faculty, University of Dicle, Diyarbakır - Turkey.
} 
significance of inflammation in diseases. In various diseases such as infectious, inflammatory and neoplastic, an elevation was detected in the serum levels of ICAM-1 (Huang et al., 2005).

In the present study, it is aimed to reveal whether the expression of ICAM-1, which increases in case of inflammation, changes based on the age in the aortic endothelial cells of healthy rats.

\section{MATERIAL AND METHOD}

For the present study, 30 adult Wistar albino rats were obtained from the Sabahattin Payzın Health Sciences Research and Application Centre of Dicle University. The rats were maintained under a $12 \mathrm{~h}$-light $/ 12 \mathrm{~h}$-dark cycle throughout the experiment. The ambient temperature $\left(22^{\circ} \mathrm{C}\right)$ and relative humidity $(45 \%)$ maintained throughout the experiments. The animals were provided with pellet food and water ad libitum. The rats were randomly divided into three groups, each comprising ten animals. Age related changes of the ICAM-1 expression investigated in 6-month-old (adult), 18-month-old (adult) and 24-month-old (aged) male and female in Wistar albino rat. The rats maintained and fed standard pellet food ad libitum during the study. All animals received human care according to criteria outlined in the "Guide for the Care and Use of Laboratory Animals" prepared by the National Academy of Sciences and Published by the National Institutes of Health. The animals were handled in accordance with the guidelines of Dicle University on the care and use of animals (HADEK-2005/40). At the end of study; all the rats were sacrificed under lethal dose of pentothal anesthesia.

The aortic tissues were fixed for 6-8 hours in Bouin's solution at $4{ }^{\circ} \mathrm{C}$. They were dehydrated through increasing concentrations of the ethanol series and the tissues were embedded in paraffin and cut into $4-5 \mathrm{~mm}$ transversal, dewaxed in xylene, and incubated for 20 minutes in $0.3 \% \mathrm{H}_{2} \mathrm{O}_{2}$ to block endogenous peroxidase activity. Sections then were microwaved for 4 minutes in $20 \%$ goat serum in PBS in order to avoid undesired background staining, put into 20 minutes.

\section{Monoclonal mouse anti-Human ICAM-1 (BioGenex San Ramon USA) primary antibody (dilution: 1/200) was} applied to the sections for 3 hours at $37^{\circ} \mathrm{C}$ in a humidified staining chamber. Sections were then incubated in anti-mouse IgG secondary antibody (Lab Vision, dilution: 1/1000) for 1 hour, and they were put into the APAAP complex for an hour. Sections were mounted with a glycerol-PBS mixture (1:1 glycerol: PBS). Following this step, sections were incubated in the fast red/TR naphtol mixture until the specific regions were stained red, and then the sections were either briefly put into Mayer's hematoxylene in order to visualize the nuclei, or were not subjected to counterstaining. Sections were mounted with a glycerol-PBS mixture (1:1 glycerol: PBS). The immunohistochemical expressions were evaluated in 3 categories such as mild, moderate, and intense. The microphotographs were taken by Nikon 400 Eclipse light microscope.

\section{RESULTS}

The expression of ICAM-1 was determined in the aortic endothelial cells of each age group. Staining was not observed in the negative controls for each age group (Fig. 1). The degree of staining was mild, medium and dense in 6-month rats, 18month rats and 24-month rats, respectively (Table I).

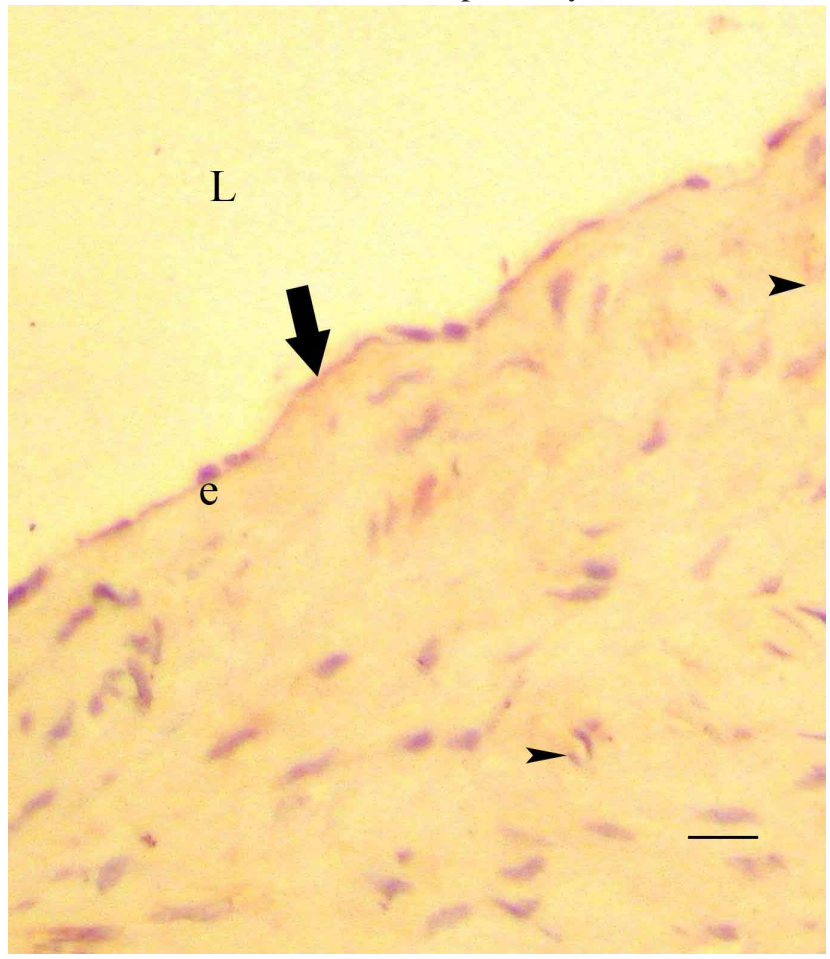

Fig. 1. Histological appearance of negative control groups (6 months). ICAM-1 was not seen in aorta endothelium (arrows), lumen of aort (L), capiller (k) Immunostaining was performed using secondary antibodies (Original magnification X 20).

Table I. Immunohistochemical expression of ICAM-1 in the age related changes.

\begin{tabular}{lc}
\hline \multicolumn{1}{c}{ Groups } & ICAM-1 Expression \\
\hline Group I -6-month-o ld (ad ult) rat & \pm \\
Group II -1 8-month-old (adult) rat & ++ \\
Group III -24-month-old (aged) & +++ \\
\hline+++ : intense staining, +: moderate staining, \pm : mild staining
\end{tabular}




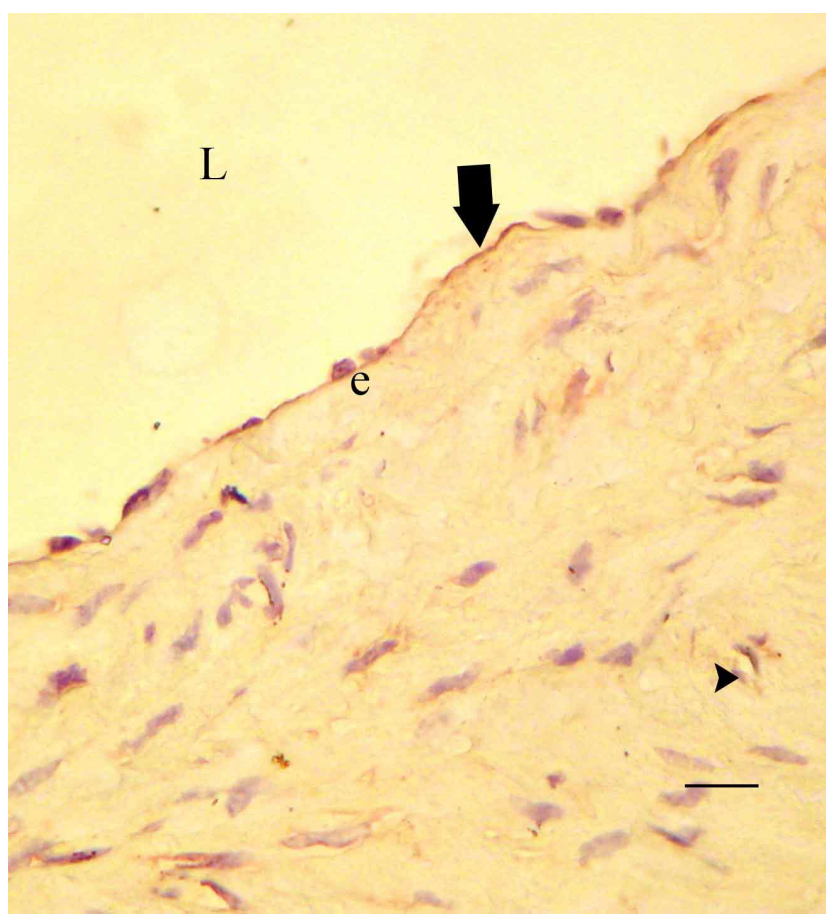

Fig. 2. 6-month-old in rat aort. ICAM-1 mild staining was seen in aorta endothelium (arrows), endothel (e), lumen of aort (L), capiller (arrowhead). (Original magnification X 20).

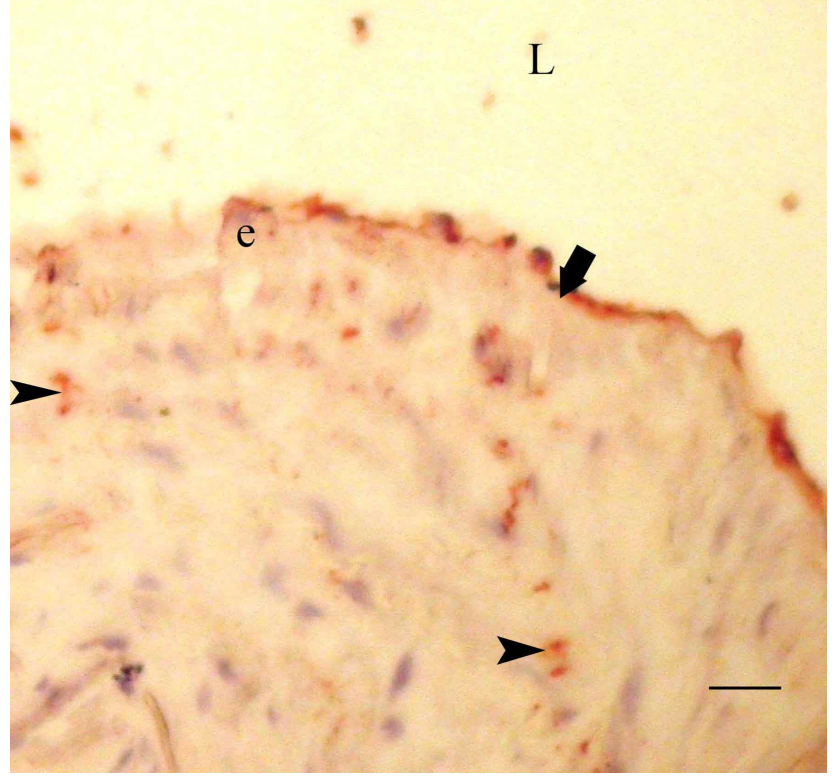

Fig. 3. 18-month-old in rat aort. ICAM-1 modarate staining was seen in aorta endothelium (arrows), endothel (e), lumen of aort (L), capiller (arrowhead). (Original magnification X 20).

In six-month rats, besides the mild expression of ICAM-1 in aortic endothelial cells, it was also mild at the

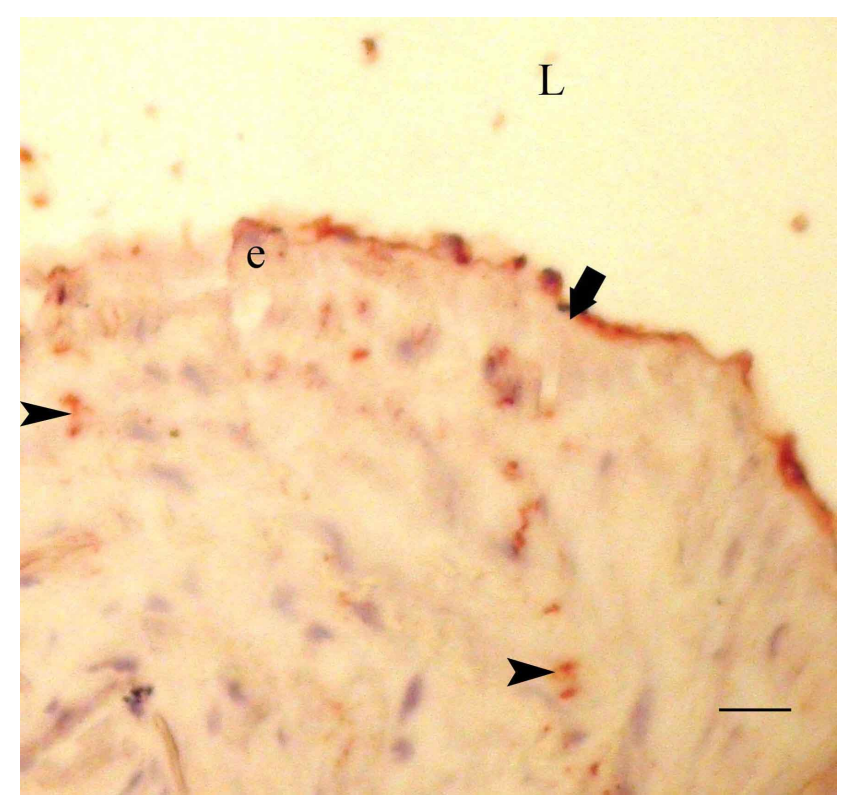

Fig. 4. 24-month-old in rat aort. ICAM-1 intense staining was seen in aorta endothelium (arrows), endothel (e), lumen of aort (L), capiller (arrowhead). (Original magnification X 20).

media layer of veins of endothelial cells (Fig. 2). In eightmonth rats, besides the medium expression of ICAM-1 in aortic endothelial cells, the expression of ICAM-1 was also much higher at the media layer of veins of endothelial cells (Fig. 3). In 24-month rats, besides the dense staining of ICAM-1 in the aortic endothelial cells, dense staining was also determined at the media layer of veins of endothelial cells (Fig. 4). It was determined that the expression of ICAM1 at the media layer of veins of endothelial cells shows increase according to the age in each age group.

The expression of ICAM-1 has been significantly increased based on the age in both aortic endothelial cells and vein endothelial cells at the media layer.

\section{DISCUSSION}

The expression of ICAM-1, which is normally expressed at low levels in most of the cells, such as endothelial cells, lymphocytes and monocytes, is significantly enhanced by the effect of cytokines such as IL-1- TNF-alpha and IFNgamma. This enhancement is shaped in the areas of acute and chronic inflammation. ICAM-1 is combined with LFA-1 which is found in all leukocytes of integrin family and mainly with macrophage antigen-1 (Mac-1) which is present in neutrophils, monocytes and eosinophils (Hernandez-Caselles et al.; van de Stolpe \& van der Saag). 
It has been reported that ICAM-1 is seen as a first marker in injections such as Malaria, HIV-1 and allergic rhinitis, and in diseases such as transplant rejection, diabetes and atherosclerosis. Moreover, the plasma levels of ICAM-1 shows parallelism with the significance of inflammation in diseases and it is elevated in various diseases such as infectious, inflammatory and neoplastic (Li et al., 1999; Hajilooi et al., 2004; Huang et al.; Miller et al., 2007; Fotis et al., 2012).

In the present study, it is aimed to reveal whether the expression of ICAM-1, changes based on the age in healthy rats. For this purpose, we determined the localization and expression of ICAM-1 immunohistochemically in the aortic endothelial cells of healthy rats.

The expression of ICAM-1 was detected in the endothelial cells in various inflammatory cases especially in infectious diseases both in vivo and in vitro studies (Reiss et al., 1998; Deeths \& Mescher, 1999; Fotis et al.; Hajilooi et al.;).

ICAM-1 is one of the surface receptors activating the proliferation of endothelial cells of rats. The expression of ICAM-1 in veins of human, rabbit and mice has been reported in studies (Ulger et al., 2002). In this study, the expression of ICAM-1 was found to be positive in the aortic endothelial cells of rats.

Ulger et al., performed a study on pregnant rats and their fetuses, and they examined samples obtained from the aorta, lung, liver, hearth and kidney at different pregnancy periods $(11.5,13.5,15.5,17.5$ and 19.5). They found that the expression of ICAM-1 was not determined at the aorta and liver samples of mother and at the yolk sac of fetuses at the age of 11.5 and 13.5 days. In our study, ICAM-1 was expressed in aortic endothelial cells of 6-, 18- and 24-month rats.

In a study based on the expression of ICAM-1 on the aortic endothelial cells of rabbits by giving various doses of propofol, Ketani et al. (2009), found that the expression of ICAM-1 was significantly enhanced by the increase of propofol dose. Ramot et al. (2007), was stated that the expression of ICAM-1 was increased based on age in rats with hemolytic anemia. In a study performed on rat liver by Nicoletti et al. (1996), the differences at the expression of ICAM-1 was compared in rats with trimmed hepatic vein and rats having pseudo operated hepatic veins. In operated rats, the expression of ICAM-1 was reported in large veins of endothelial cells after one month, however, it was found to be rare at the arterial and capillary endothelial tissues. On the other hand, expression was determined at the arterial and capillary endothelial tissues four months after the operation.
After the operation, the expression of ICAM-1 was rare on the adventitia layer of the arteries, the level of ICAM expression was found to be higher four months after the operation when it was compared to the one-month post-op rats and there was no difference between the expression levels of ICAM in operated and trimmed rats after the operation and 4 months, respectively. The expression of ICAM was reported in all venous endothelial tissues of rats with trimmed vein regardless of time.

In a study conducted on rat at different age $(3,6,9$, 12, 18, 24 months), Miller et al., noted elevated ICAM-1 expression based on age. In our study, a significant increase was determined in the aortic endothelial cells of healthy rats with increasing age. Our findings were verified with the study of Miller et al.

In a study performed by Li et al., ICAM-1 was not found to be expressed on thoracic aortas of 6-and 30-month old rats. In our study, the expression of ICAM-1 was determined not only on intima layer of aorta but also in the endothelial cells of veins found on media layer.

In recent studies, it was determined that age is the most significant risk factor in development of coronary disease (Hajilooi et al.; Miller et al.). In human studies, ICAM-1 was found to be a risk factor in coronary diseases by itself (Hajilooi et al.). In a study performed by Aydin et al. (1995) the serum levels of thyroxine was decreased by giving radioactive iodine in rats, and atherosclerotic variations was determined in large veins which are more significant in late period samples. When it is considered that the atherosclerotic changes shows increase with increasing age, age might be evaluated as a risk factor in coronary diseases due to the simultaneous increase of ICAM1 expression with age in endothelial cells.

In conclusion, the age-dependent expression of ICAM1 in rats was found to be at various levels both in intima and media layer of endothelial cells. The studies have shown that the expression of ICAM-1 is increased especially in case of infection. It was thought that the expression of ICAM-1 which is enhanced according to the age, is an indicative factor in order to reveal the importance of age in case of infection.

KETANI, S.; KARAKOÇ, Z.; KETANI, M. A. \& KILINÇ, M. Cambios relacionados con la edad en la expresión de ICAM-1 en la aorta de ratas Wistar albinas. Int. J. Morphol., 34(4):1482-1486, 2016.

RESUMEN: ICAM-1, que se expresa en las células endoteliales y los leucocitos, se observan como primeros marcadores de enfermedades como el rechazo de trasplante, la diabetes y la aterosclerosis y en las infecciones causadas por diversos patógenos. 
En el presente estudio, se pretende revelar los cambios relacionados con la edad en la expresión de ICAM-1 en ratas. Un total de 30 ratas albinas fueron seleccionadas con edades de 6,18 y 24 meses, sin discriminación de sexo. Durante el estudio se administró a las ratas alimentación estándar de pellets. Posteriormente, los animales fueron sacrificados y se recogieron muestras de sus tejidos, los cuales fueron teñidos para inmunohistoquímica y se evaluaron a través de microscopio óptico. Se determinó que la expresión tanto de células endoteliales aórticas como de células endoteliales de la capa media se incrementó significativamente en función de la edad.

PALABRAS CLAVE: ICAM-1; Ratas; Endotelio aórtico;

Edad.

\section{REFERENCES}

Aydın, I.; Nergiz, Y.; Aslan, I.; Bahçeci, M. \& Ketani, A. The effect of serum thyroxin insufficiency and gonadectomy on the atherosclerotic alterations. U. E. D., 5(3):311-21, 1995.

Deeths, M. J. \& Mescher, M. F. ICAM-1 and B7-1 provide similar but distinct costimulation for CD8+ T cells, while CD4+ T cells are poorly costimulated by ICAM-1. Eur. J. Immunol., 29(1):4553, 1999.

Fotis, L.; Agrogiannis, G.; Vlachos, I. S.; Pantopoulou, A.; Margoni, A.; Kostaki, M.; Verikokos, C.; Tzivras, D.; Mikhailidis, D. P. \& Perrea, D. Intercellular adhesion molecule (ICAM)-1 and vascular cell adhesion molecule (VCAM)-1 at the early stages of atherosclerosis in a rat model. In Vivo, 26(2):243-50, 2012.

Frenette, P. S. \& Wagner, D. D. Adhesion molecules--Part 1. N. Engl. J. Med., 334(23):1526-9, 1996.

Funatsu, O.; Sato, T.; Kotovuori, P.; Gahmberg, C. G.; Ikekita, M. \& Furukawa, K. Structural study of N-linked oligosaccharides of human intercellular adhesion molecule-3 (CD50). Eur. J. Biochem., 268(4):1020-9, 2001.

Hajilooi, M.; Sanati, A.; Ahmadieh, A.; Ghofraniha, A. \& Massoud, A. Circulating ICAM-1, VCAM-1, E-selectin, P-selectin, and TNFRII in patients with coronary artery disease. Immunol. Invest., 33(3):263-75, 2004.

Hernandez-Caselles, T.; Rubio, G.; Campanero, M. R.; del Pozo, M. A.; Muro, M.; Sanchez-Madrid, F. \& Aparicio, P. ICAM-3, the third LFA-1 counterreceptor, is a co-stimulatory molecule for both resting and activated T lymphocytes. Eur. J. Immunol., 23(11):2799-806, 1993.

Holtfreter, J. Significance of the cell membrane in embryonic processes. Ann. N. Y. Acad. Sci., 49(Art. 5):709-60, 1948.

Huang, Q.; Shao, L.; He, M.; Chen, H.; Liu, D.; Luo, Y. \& Dai, Y. Inhibitory effects of sasanquasaponin on over-expression of ICAM-1 and on enhancement of capillary permeability induced by burns in rats. Burns, 31(5):637-42, 2005.
Ketani, M. A.; Kanay, E. B.; Ketani, S.; Ünver, Ö. \& Kilinç, M. Dose-dependent effects of propofol on expression ICAM-1 in rabbit aorta endothelial cells. Afr. J. Biotechnol., 8(23):6688-93, 2009.

Li, Z.; Froehlich, J.; Galis, Z. S. \& Lakatta, E. G. Increased expression of matrix metalloproteinase- 2 in the thickened intima of aged rats. Hypertension, 33(1):116-23, 1999.

Miller, S. J.; Watson, W. C.; Kerr, K. A.; Labarrere, C. A.; Chen, N. X.; Deeg, M. A. \& Unthank, J. L. Development of progressive aortic vasculopathy in a rat model of aging. Am. J. Physiol. Heart Circ. Physiol., 293(5):H2634-43, 2007.

Nicoletti, A.; Mandet, C.; Challah, M.; Bariéty, J. \& Michel, J. B. Mediators of perivascular inflammation in the left ventricle of renovascular hypertensive rats. Cardiovasc. Res., 31(4):585-95, 1996.

Ramot, Y.; Lewis, D. A.; Ortel, T. L.; Streicker, M.; Moser, G.; Elmore, S.; Ward, S. M.; Peddada, S. \& Nyska, A. Age and dose sensitivities in the 2-butoxyethanol F344 rat model of hemolytic anemia and disseminated thrombosis. Exp. Toxicol. Pathol., 58(5):311-22, 2007.

Reiss Y.; Hoch, G.; Deutsch U. \& Engelhardt, B. T cell interaction with ICAM-1-deficient endothelium in vitro: essential role for ICAM-1 and ICAM-2 in transendothelial migration of T cells. Eur. J. Immunol., 28(10):3086-99, 1998.

Springer, T. A. Adhesion receptors of the immune system. Nature, 346(6283):425-34, 1990.

Ulger, H.; Karabulut, A. K. \& Pratten, M. K. Labelling of rat endothelial cells with antibodies to vWF, RECA-1, PECAM-1, ICAM-1, OX-43 and ZO-1. Anat. Histol. Embryol., 31(1):31-5, 2002.

van de Stolpe, A. \& van der Saag, P. T. Intercellular adhesion molecule-1. J. Mol. Med. (Berl.), 74(1):13-33, 1996.

Corresponding author:

Zelal KARAKOÇ

Department of Histology and Embryology

Veterinary Medicine Faculty

University of Siirt

Siirt

Turkey.-

E-mail: zelalkarakoc@siirt.edu.tr

Received: 23-05-2016

Accepted: 02-09-2016 